Vol. 3, Issue 1, Mei 2019

P-ISSN: 2527-8479

\title{
DAMPAK KEBIJAKAN ANGGARAN PEMASARAN TERHADAP VOLUME PENJUALAN PRODUK MIE INSTAN PT INDOFOOD CBP SUKSES MAKMUR, TBK DI KOTA BAUBAU
}

\author{
Antasalam Ajo \\ Program Studi Agribisnis Fakultas Pertanian \\ Universitas Muhammadiyah Buton \\ J1.Betoambari No. 36 Baubau \\ e-mail : antasalampk@yahoo.com
}

\begin{abstract}
This study aims to 1) analyze the influence of the marketing budget policy to the volume of product sales of instant noodles in the PT. Indofood CBP Sukses Makmur, Tbk in Baubau, 2) a portrait of the volume of product sales of instant noodles in the PT. Indofood CBP Sukses Makmur, Tbk in Baubau. In this study the research variables consisted of the dependent variable is the volume of sales, and independent variables consisting of: distribution costs, advertising costs, costs outlets, and promotional costs. Apart from that necessary support is also variable: the number of workers, number of receipt of goods, the amount of budget, schedule the use of budgets, types of sales activities, and the selling price. Data were analyzed using multiple linear regression analysis, and trend analysis of sales volume. The study produced several conclusions, among others, promotional costs, advertising costs, costs associated outlets and distribution costs and simultaneously positively and significantly influenced the partial volume of product sales of instant noodles in the PT. Indofood CBP Success prosperous, Tbk Baubau. Based on the value of elasticity, promotional expenses increased $1 \%$ then it will increase the sales volume of $0.004 \%$, advertising expenses increased $1 \%$ then it will increase the sales volume of $0.002 \%$, expenses increased $1 \%$ then the outlet will increase the sales volume of $0.001 \%$, and distribution costs increased $1 \%$, then will increase the sales volume of 0 001\%. Volume sales of instant noodle products at PT. Indofood CBP Sukses Makmur, Tbk Baubau in 2010 to 2014 has increased by an average of 159.406 billion rupiah per year while the year 2011 to 2015 the average sales volume will reach 197.315 billion rupiah per year.
\end{abstract}

Keywords: marketing budget policies and trends in sales volume.

\begin{abstract}
Abstrak
Penelitian ini bertujuan untuk 1) menganalisis pengaruh kebijakan anggaran pemasaran terhadap volume penjualan produk mie instan pada PT. Indofood CBP Sukses Makmur, Tbk di Baubau, 2) mengambarkan volume penjualan produk mie instan pada PT. Indofood CBP Sukses Makmur, Tbk di Baubau. Variabel penelitian terdiri dari variabel dependen yakni volume penjualan, dan variabel independen yang terdiri dari biaya distribusi, biaya iklan, biaya outlet, dan biaya promosi. Variabel penunjang yaitu jumlah tenaga kerja, jumlah penerimaan barang, jumlah anggaran, jadwal penggunaan anggaran, jenis kegiatan penjualan, dan harga jual. Data dianalisis dengan menggunakan analisis regresi linear berganda dan analisis trend volume penjualan. Kesimpulan penelitian antara lain biaya promosi, biaya iklan, biaya outlet dan biaya distribusi berhubungan positif dan secara simultan maupun
\end{abstract}


parsial berpengaruh nyata terhadap volume penjualan produk mie instan pada PT. Indofood CBP Sukses makmur, Tbk Baubau. Berdasarkan nilai elastisitasnya, biaya promosi ditingkatkan $1 \%$ maka akan meningkatkan volume penjualan $0,004 \%$, biaya iklan ditingkatkan $1 \%$ maka akan meningkatkan volume penjualan $0,002 \%$, biaya outlet ditingkatkan $1 \%$ maka akan meningkatkan volume penjualan $0,001 \%$, dan biaya distribusi ditingkatkan $1 \%$ maka akan meningkatkan volume penjualan $0,001 \%$. Volume penjualan produk mie instan pada PT. Indofood CBP Sukses Makmur, Tbk Baubau pada tahun 2010 sampai 2014 mengalami peningkatan dengan rata-rata 159,406 miliar rupiah per tahun sedangkan tahun 2011 sampai 2015 volume penjualan rata-rata akan mencapai 197,315 miliar rupiah per tahun.

Kata kunci : Kebijakan anggaran pemasaran dan trend volume penjualan.

\section{PENDAHULUAN}

\section{Latar Belakang}

PT. Indofood CBP Sukses Makmur, Tbk sebagai salah satu perusahaan multinasional yang bergerak di bidang pengolahan produk-produk agribisnis pertanian menjadi produkproduk instan yang siap dikonsumsi seperti Indomie, kecap dan produk-produk makanan lainnya juga memiliki cabang-cabang produksi dan cabang pemasaran di berbagai daerah di Indonesia. Salah satu cabang produksi adalah di Makassar Sulawesi Selatan, dan memiliki cabang-cabang pemasaran di berbagai daerah di Indonesia Timur. Salah satu cabang jaringan pemasaran PT. Indofood CBP Sukses Makmur, Tbk Cabang Makassar adalah di Kota Baubau Sulawesi Tenggara. Khusus cabang pemasaran PT. Indofood CBP Sukses Makmur, Tbk di Baubau, perkembangan anggaran yang diterima daiam 5 tahun terakhir (2010-2014) adalah seperti pada Tabel 1. Terlihat bahwa kebijakan penggunaan anggaran yang dilakukan mengalami peningkatan berdasarkan quartal, namun anggaran tersebut sering tidak dapat mencukupi kegiatan yang dilakukan oleh perusahaan.

PT. Indofood CBP Sukses Makmur, Tbk di Baubau sebagai salah satu kantor pemasaran di wilayah Sulawesi Tenggara hanya diberikan proporsi anggaran penjualan sebesar 30 persen dari anggaran yang disalurkan oleh kantor pusat di Jakarta melalui Cabang Makassar. Kegiatannya meliputi promosi penjualan, iklan, dan event untuk mempertahankan pasar dan memperluas pangsa pasamya.

Berdasarkan kondisi ini, maka manajer cabang mengatur penggunaan anggaran agar tujuan perusahaan untuk memperoleh volume penjualan serta laba yang optimal secara kontinyu dapat tercapai. Dibutuhkan perencanaan dan pengendalian anggaran yang tepat agar tidak menghambat aktivitas penjualan produk ke semua tempat yang rnenjadi area pemasarannya.

\section{Rumusan Masalah}

1. Apakah Kebijakan anggaran pemasaran berpengaruh terhadap volume penjualan produk mie instan pada PT. Indofood CBP Sukses Makmur, Tbk di Baubau.

2. Bagaimana trend volume penjualan produk mie instan pada PT. Indofood CBP Sukses Makmur, Tbk di Baubau.

\section{Kerangka Pemikiran}


Kebijakan anggaran pemasaranmerupakan bagian dari manajemen keuangan suatu perusahaan. Anggaran yang disusun setiap tahun atau secara periodik untuk memenuhi berbagai kebutuhan perusahaan. Besarnya anggaran yang disusun tergantung pada kegiatan yang akan dilakukan perusahaan dalam rangka peningkatan volume penjualan. Akan tetapi dalam kenyataannya, realisasi dari anggaran yang disusun oleh masing-masing cabang perusahaan tidak selalu disetujui seluruhnya oleh induk perusahaan sehingga diperlukan kebijakan anggaran pada cabang-cabang perusahaan.

Alokasi anggaran digunakan untuk memperlancar dan mewujudkan pelaksanaan kegiatan perusahaan yang ditujukan untuk menyalurkan dan memasarkan produk kepada konsumen akhir baik secara langsung maupun melalui mitra kerja seperti toko, kios dan swalayan. Selain dari itu anggaran dialokasikan juga untuk pembuatan iklan, kegiatan promosi dan insentif kepada karyawan yang berprestasi. Jika volume penjualan meningkat dari waktu ke waktu maka laba perusahaan akan meningkat pula dalam satu satuan waktu tertentu.

\section{Lokasi Penelitian}

\section{METODE PENELITIAN}

Sesuai dengan judul maka lokasi penelitian ini adalah pada PT.Indofood CBP Sukses Makmur, Tbk di Baubau. Pemilihan lokasi didasarkan pada kesesuaian tujuan penelitian yaitu adanya kebijakan anggaran yang disusun secara periodik oleh perusahaan.

\section{Teknik Pengumpulan Data}

Data penelitian ini dikumpulkan dengan menggunakan teknik wawancara langsung kepada pimpinan dan staf perusahaan sehubungan dengan kebijakan anggaran perusahaan dalam meningkatkan penjualan.Selain dari itu dilakukan pencatatan terhadap data-data sekunder yang telah tersedia dalam laporan bulanan dan laporan tahunan perusahaan.

\section{Teknik Analisis}

Data dianalisis dengan teknik sebagai berikut:

\section{Analisis Regresi Linear Berganda}

Analisis pengaruh kebijakan anggaran pemasaran terhadap volume penjualan digunakan analisis regresi linear berganda dengan rumus :

$\mathrm{Y}=\mathrm{a}+\mathrm{b}_{1} \mathrm{X}_{1}+\mathrm{b}_{2} \mathrm{X}_{2}+\mathrm{b}_{3} \mathrm{X}_{3}+\mathrm{b}_{4} \mathrm{X}_{4}+\mathrm{e}$

Dimana :

$\mathrm{Y}=$ Volume Penjualan (Rupiah)

a $=$ konstanta

$\mathrm{b}=$ koefisien regresi

$\mathrm{X}_{1}=$ Biaya Promosi (Rupiah)

$\mathrm{X}_{2}=$ Biaya lklan (Rupiah)

$\mathrm{X}_{3}=$ Biaya Outlet (Rupiah)

$\mathrm{X}_{4}=$ Biaya Distribusi (Rupiah)

e $=$ Error Term

Tanda parameter dugaan yang diharapkan bj $>0$. Hal itu bermakna apabila nilai Biaya Distribusi ( $\left.\mathrm{X}_{(}\right)$Biaya lklan $\left(\mathrm{X}_{2}\right)$ Biaya Outlet $\left(\mathrm{X}_{3}\right)$ dan Biaya Promosi $\left(\mathrm{X}_{4}\right)$ meningkat maka nilai Volume Penjualan (Y) akan meningkat, dan sebaliknya jika nilai Biaya Distribusi $\left(\mathrm{X}_{1}\right)$ Biaya lklan $\left(\mathrm{X}_{2}\right)$ Biaya Outlet $\left(\mathrm{X}_{3}\right)$ dan Biaya Promosi $\left(\mathrm{X}_{4}\right)$ menurun maka nilai Volume Penjualan (Y) akan menurun. 


\section{Pengujian Hipotesis}

\section{a. Uji F}

Untuk melihat pengaruh Biaya Promosi $\left(\mathrm{X}_{1}\right)$ Biaya lklan $\left(\mathrm{X}_{2}\right)$ Biaya Outlet $\left(\mathrm{X}_{3}\right)$ dan Biaya Distribusi $\left(\mathrm{X}_{4}\right)$ terhadap volume penjualan $(\mathrm{Y})$ bersama - sama dilakukan uji $\mathrm{F}$ dengan menggunakan rumus F hitung (Riduwan, 2006):

$F_{\text {hitung }}=\frac{\frac{R^{2}}{k}}{\frac{\left(1-R^{2}\right)}{n-k-1}}$

Dimana:

$\mathrm{F}_{\text {hitung }}=$ Nilai $\mathrm{F}$ yang dihitung

$\mathrm{R}=$ Nilai koefisien korelasi ganda

$\mathrm{K}=$ Jumlah variabel bebas (independent)

$\mathrm{n} \quad=$ Jumlah sampel

Untuk pengujian $\mathrm{F}$, digunakan hipotesis sebagai berikut:

$\mathrm{H}_{0}: \quad \mathrm{bi}=0$

$\mathrm{H}_{\mathrm{A}}: \quad \mathrm{b}_{\mathrm{i}} \neq 0$

Pengujian ini dilakukan dengan membandingkan nilai $F_{\text {hitung }}$ dengan nilai $F_{\text {tabel. }}$ Jika nilai Fhitung $\mathrm{F}_{\text {tabel }}$ maka $\mathrm{H}_{0}$ ditolak, berarti Biaya Promosi $\left(\mathrm{X}_{1}\right)$ Biaya lklan $\left(\mathrm{X}_{2}\right)$ Biaya Outlet $\left(\mathrm{X}_{3}\right)$ dan Biaya Distribusi $\left(\mathrm{X}_{4}\right)$ secara bersama-sama mempengaruhi volume penjualan $(\mathrm{Y})$. Dan sebaliknya apabila $F_{\text {hitung }}<F_{\text {tabel }}$ maka Ho diterima yang berarti bahwa Biaya Promosi $\left(\mathrm{X}_{1}\right)$ Biaya lklan $\left(\mathrm{X}_{2}\right)$ Biaya Outlet $\left(\mathrm{X}_{3}\right)$ dan Biaya Distribusi $\left(\mathrm{X}_{4}\right)$ secara bersama-sama tidak mempengaruhi volume penjualan $(\mathrm{Y})$.

Penelitian ini berhubung menggunakan Software Statistical Product and Service Solution (SPSS) versi 19 maka kriteria yang digunakan sebagai berikut:

1. Jika nilai signifikan $F_{\text {hitung }}<$ taraf nyata yang digunakan $(\alpha=0,05)$, menunjukan variabel bebas $(\mathrm{X})$ secara bersama-sama berpengaruh nyata terhadap variabel tak bebas.

2. Jika nilai signifikan $F_{\text {hitung }}>$ taraf nyata yang digunakan $(\alpha=0,05)$, menunjukkan variabel bebas $(\mathrm{X})$ secara bersama sama tidak berpengaruh nyata terhadap variabel tak bebas (Y).

\section{b. Uji t}

Selanjutnya untuk melihat signifikan dari pengaruh Biaya Promosi $\left(\mathrm{X}_{1}\right)$ Biaya Iklan $\left(X_{2}\right)$ Biaya Outlet $\left(X_{3}\right)$ dan Biaya Distribusi $\left(X_{4}\right)$ secara individu mempengaruhi volume penjualan (Y) dilakukan uji t, dengan rumus t hitung dengan menggunakan rumus (Riduwan, 2006) :

Dimana :

$$
\mathrm{T}_{\text {hitung }}=\frac{r \sqrt{n-2}}{\sqrt{n-r^{2}}}
$$

$\mathrm{T}_{\text {hitung }}=$ Nilai $\mathrm{t}$

$\mathrm{r}=$ Nilai koefisien korelasi Sederhana 
$\mathrm{n}=$ Jumlah sampel

Dengan hipotesis sebagai berikut :

$\mathrm{H}_{0} \quad$ : $\mathrm{bi}=0$

$\mathrm{H}_{\mathrm{A}} \quad: \mathrm{bi} \neq 0$

Pengujian ini dilakukan

dengan membandingkan nilai thitungdengan nilai $t_{\text {tabel }}$ Bila nilai

$t_{\text {hitung }}>t_{\text {tabel }}$, maka Ho ditolak. Hal ini berarti bahwa Biaya Distribusi $\left(\mathrm{X}_{1}\right)$ Biaya Iklan $\left(\mathrm{X}_{2}\right)$

Biaya Outlet $\left(\mathrm{X}_{3}\right)$ dan Biaya Promosi $\left(X_{4}\right)$, yang diuji berpengaruh secara nyata terhadap

volume penjualan $(\mathrm{Y})$. Sebaliknya jika nilai $\mathrm{t}_{\text {hitung }}<\mathrm{t}_{\text {tabet }}$ maka $\mathrm{H}_{0}$ diterima. Adapun tingkat signifikan yang ditentukan adalah $95 \%$ atau $\alpha=5 \%(0,05)$.

Penelitian ini menggunakan Software Statistical Product and Service Solution (SPSS) versi 19 maka kriteria yang digunakan sebagai berikut:

1. Jika nilai signifikan thitung $<$ taraf nyata yang digunakan $(\alpha=0,05)$, menunjukan variable bebas $(\mathrm{X})$ secara parsial berpengaruh nyata terhadap variabel tak bebas $(\mathrm{Y})$.

2. Jika nilai signifikan $t_{\text {hitung }}>$ taraf nyata yang digunakan $(\alpha=0,05)$, menunjukkan variable bebas $(\mathrm{X})$ secara parsial berpengaruh tidak nyata terhadap variabel tak bebas $(\mathrm{Y})$.

\section{Analisis Trend}

Untuk menggambarkan trend volume penjualan digunakan analisis time series dengan rumus sebagai berikut:

Dimana:

$$
\mathrm{Y}=\mathrm{a}+\mathrm{bX}
$$

$\mathrm{Y}=$ Volume penjualan yang akan datang

$\mathrm{a}=$ konstanta

$\mathrm{b}=$ koefisien regresi

$\mathrm{X}=$ periode penjualan tahun $\mathrm{X}$

\section{PEMBAHASAN}

\section{A. Implernentasi Kebijakan Anggaran}

Suhyani (2000) menjelaskan bahwa kebijakan anggaran dalam suatu perusahaan merupakan keputusan-keputusan yang menyeluruh terhadap pengelolaan anggaran perusahaan. Dalam hal ini kebijakan anggaran ditetapkan setiap tahun melalui suatu proses pengambilan keputusan oleh para pemimpin perusahaan. Tahapan penentuan kebijakan anggaran terdiri dari tiga langkah yaitu perencanaan, pengelompokkan penggunaanserta pengawasan anggaran.

Kegiatan perusahaan pemasaran dan distributor dari PT. Indofood CBP Sukses Makmur, Tbk dengan anggaran yang diajukan kepada perusahaan pusat adalah kegiatankegiatan yang mencakup: (a) promosi penjualan, (b) iklan, (c) outlet, dan (d) distribusi. Masing-rnasing sebagai berikut:

\section{a. Promosi Penjualan}

Promosi penjualan fokus pada harga produk dan setiap unit produk mie instan yang terjual diberikan potongan harga serta syarat beli seperti beli satu dapat dua atau beli satu gratis satu.Ini model-model promosi penjualan yang membutuhkan biaya besar untuk dapat 
meningkatkan volume penjualan, dimana perusahaan ikut bertanggung jawab langsung dalam ajang promosi penjualan dan risiko kerugian selalu mengancam hasil penjualan.

Sementara itu untuk meningkatkan penjualan dengan bentuk promosi penjualan membutuhkan biaya promosi yang besar untuk nantinya akan dapat memperoleh pangsa pasar yang lebih luas. PT. Indofood CBP Sukses Makmur, Tbk Baubau melakukan kegiatan promosi penjualan pada setiap awal tahun, pertengahan tahun dan akhir tahun. Hal ini sesuai dengan jadwal penganggaran keuangan yang dilakukan manajemen perusahaan pemasaran.

Strategi promosi penjualan berkaitannya dengan strategi promosi penjualan adalah sebagai berikut:

1. Bauran promosi, terdiri atas :
a) Personal selling, komunikasi langsung antara penjual dan calon pelanggan. Komunikasi bisnis yang dibangun berkaitan dengan komunikasi harga dan jumlah barang serta kegiatan pemesanan kembali sebagai bentuk dari loyal itas pelanggan terhadap produk mie instan.
b) Mass selling, menyangkut penggunaan media komunikasi dalam promosi seperti media cetak dan media elektronik seperti radio dan televisi.
c) Promosi penjualan, bentuk persuasive langsung melalui penggunaan berbagai insentif/perangsang seperti promo harga, dan promo produk yang menjadi rangkaian kerja perusahaan pemasaran.
d) Public relations, merupakan upaya komunikasi menyeluruh untuk mempengaruhi pangsa pasarnya.
e) Direct marketing, penjualan langsung tanpa perantara.

2. Strategi promosi, meliputi :
a) Strategi pengeluaran promosi, berdasarkan besarnya anggaran promosi dalam anggaran pemasaran.
b) Strategi bauran promosi, berupaya memberikan distribusi yang optimal dari setiap metode promosi yang dilakukan.

Promosi yang dilakukan adalah mengadakan acara undian, event-event dan demo masak untuk keluarga dengan tujuan untuk memperkenalkan produk mie instan kepada masyarakat, bekerja sama dengan perusahaan distributor. Strategi untuk tujuan ini nampak pada acara undian, event-event dan demo masak seperti yang dikemukakan oleh Sekretaris Manajer bahwa perusahaan menyediakan anggaran promosi untuk membangun daya tarik konsumen terhadap produk mie instan. Biaya Promosi Penjualan Periode 2010-2014 yang dilakukan PT. Indofood CBP Sukses Makmur, Tbk (2014) pada Tabel 1 berikut:

Tabel 1. Biaya Promosi Penjualan Periode 2010-2014.

\begin{tabular}{ccccc}
\hline \multirow{2}{*}{ Tahun } & \multicolumn{2}{c}{ Biaya Promosi/Quartal (Rupiah) } & \multirow{2}{*}{ Jumlah (Rp) } \\
\cline { 2 - 4 } & Quartal I & Quartal II & Quartal III & \\
\hline 2010 & 19.878 .285 & 19.878 .285 & 19.878 .285 & 59.634 .855 \\
\hline 2011 & 20.099 .744 & 20.099 .744 & 20.099 .744 & 60.299 .231 \\
\hline 2012 & 20.522 .896 & 20.522 .896 & 20.522 .896 & 61.568 .689 \\
\hline
\end{tabular}




\begin{tabular}{|c|c|c|c|c|}
\hline \multicolumn{5}{|c|}{ Vol. 3, Issue 1, Mei 2019} \\
\hline \multicolumn{5}{|c|}{ P-ISSN: 2527-8479 } \\
\hline 2013 & 20.598 .395 & 20.598 .395 & 20.598 .395 & 61.795 .185 \\
\hline 2014 & 21.376 .875 & 21.376 .875 & 21.376 .875 & 64.130 .625 \\
\hline Rata-rata & 19.817 .719 & 19.817 .719 & 19.817 .719 & 59.453 .157 \\
\hline
\end{tabular}

Sumber : PT. Indofood CBP Sukses Makmur, Tbk (2014)

Tabel 1 mengindikasikan bahwa perusahaan gencar melakukan kegiatan promosi yang seiring dengan peningkatan biaya promosi. Kebijakan anggaran untuk setiap quartal dalam jumlah yang sama adalah untuk mempertahankan kegiatan promosi yang sudah dirintis sebelumnya.

\section{a. Iklan}

Menurut Kotler (1997) iklan merupakan salah satu bauran penjualan yang digunakan untuk mendekatkan konsumen atau pelanggan kepada produk yang dipasarkan. Berbagai atribut yang berhubungan dengan periklanan seperti panflet, brosur, baleho, dan atribut lainnya yang kemudian dijadikan sebagai simbol dan tujuan promosi penjualan. Perusahaan melakukan kerja sama dengan mitra kerja lainnya seperti pedagang besar, pengecer, outlet, bahkan perusahaan menggunakan konsumen tetap untuk tujuan iklan. Biaya iklan yang dilakukan PT. Indofood CBP sukses Maksmur, Tbk BauBau Periode 2010 - 2014 pada Table 2 berikut :

Tabel 2. Biaya Iklan pada PT. Indofood CBP Sukses Makmur, Tbk Baubau Periode 2010 2014.

\begin{tabular}{ccccc}
\hline \multirow{2}{*}{ Tahun } & \multicolumn{3}{c}{ Biaya Promosi/Quartal (Rupiah) } & \multirow{2}{*}{ Jumlah (Rp) } \\
\cline { 2 - 4 } & Quartal I & Quartal II & Quartal III & \\
\hline 2010 & 13.252 .190 & 13.252 .190 & 13.252 .190 & 39.756 .570 \\
\hline 2011 & 13.399 .829 & 13.399 .829 & 13.399 .829 & 40.199 .487 \\
\hline 2012 & 13.681 .931 & 13.681 .931 & 13.681 .931 & 41.045 .793 \\
\hline 2013 & 13.732 .263 & 13.732 .263 & 13.732 .263 & 41.196 .789 \\
\hline 2014 & 14.251 .250 & 14.251 .250 & 14.251 .250 & 42.753 .750 \\
\hline Rata-rata & 13.211 .813 & 13.211 .813 & 13.211 .813 & 39.635 .438 \\
\hline
\end{tabular}

Sumber : PT. Indofood CBP Sukses Makmur. Tbk (2014).

c. Outlet

Outlet merupakan salah satu tempat promosi yang dilakukan perusahaan dalam meningkatkan volume penjualan. Berikut adalah biaya Outlet yang dikeluarkan oleh PT. Indofood CBP Sukses Makmur, Tbk Baubau pada Periode 2010-2014 seperti pada Tabel 3.

Tabel 3. Biaya Outlet pada PT. Indofood CBP Sukses Makmur, Tbk Baubau Periode 2010 - 
Vol. 3, Issue 1, Mei 2019

P-ISSN: 2527-8479

2014.

\begin{tabular}{ccccc}
\hline \multirow{2}{*}{ Tahun } & \multicolumn{3}{c}{ Biaya Promosi/Quartal (Rupiah) } & \multirow{2}{*}{ Jumlah (Rp) } \\
\cline { 2 - 4 } & Quartal I & Quartal II & Quartal III & \\
\hline 2010 & 13.252 .190 & 13.252 .190 & 13.252 .190 & 39.756 .570 \\
\hline 2011 & 13.399 .829 & 13.399 .829 & 13.399 .829 & 40.199 .487 \\
\hline 2012 & 13.681 .931 & 13.681 .931 & 13.681 .931 & 41.045 .793 \\
\hline 2013 & 13.732 .263 & 13.732 .263 & 13.732 .263 & 41.196 .789 \\
\hline 2014 & 14.251 .250 & 14.251 .250 & 14.251 .250 & 42.753 .750 \\
\hline Rata-rata & 13.211 .813 & 13.211 .813 & 13.211 .813 & 39.635 .438 \\
\hline
\end{tabular}

Sumber : PT. Indofood CBP Sukses Makmur. Tbk

(Data diolah Kembali)

\section{d. Distribusi}

Distribusi sangat penting dan perannya sangat penting dalam penyaluran suatu prodak yang dipasarkan perusahaan. Sehingga pelanggan dapat menerima produk yang dipesan merasa puas dengan pelayanan yang diberikan perusahaan. Berikut adalah biaya distribusi yang dikeluarkan oleh PT. Indofood CBP Sukses Makmur, Tbk Baubau pada Periode tahun 2010 - 2014 seperti pada Tabel 4 berikut :

Tabel 4. Biaya distribusi pada PT. Indofood CBP Makmur, Tbk BauBau Periode 2010 - 2014.

\begin{tabular}{ccccc}
\hline \multirow{2}{*}{ Tahun } & \multicolumn{3}{c}{ Biaya Promosi/Quartal (Rupiah) } & \multirow{2}{*}{ Jumlah (Rp) } \\
\cline { 2 - 4 } & Quartal I & Quartal II & Quartal III & \\
\hline 2010 & 23.191 .333 & 23.191 .333 & 23.191 .333 & 69.573 .999 \\
\hline 2011 & 23.449 .701 & 23.449 .701 & 23.449 .701 & 70.349 .103 \\
\hline 2012 & 23.943 .379 & 23.943 .379 & 23.943 .379 & 71.830 .137 \\
\hline 2013 & 24.031 .461 & 24.031 .461 & 24.031 .461 & 72.094 .383 \\
\hline 2014 & 24.939 .688 & 24.939 .688 & 24.939 .688 & 74.819 .064 \\
\hline Rata-rata & 23.120 .672 & 23.120 .672 & 23.120 .672 & 69.362 .017 \\
\hline
\end{tabular}

\section{B. Estimasi Kebijakan Anggaran Terhadap Volume Penjualan}

Berdasarkan hasil analisis linear berganda diperoleh persamaan sebagai berikut:

$\mathrm{Y}=33,692+10,119 \mathrm{X}_{1}+9,138 \mathrm{X}_{2}+2.432 \mathrm{X}_{3}+2,068 \mathrm{X}_{4}$

Dimana :

$\mathrm{Y}=$ Volume Penjualan (Paipiah)

$\mathrm{a}=$ konstanta

$\mathrm{b}=$ koefisien regresi 
$\mathrm{X}_{1}=$ Biaya Promosi (Rupiah)

$\mathrm{X}_{2}=$ Biaya Iklan (Rupiah)

$\mathrm{X}_{3}=$ Biaya Outlet (Rupiah)

$\mathrm{X}_{4}=$ Biaya Distribusi (Rupiah)

\section{Pengujian Model}

Ketetapan model dapat dilihat dari hasil uji $\mathrm{F}$, diperoleh nilai $\mathrm{F}$ hitung $=17,417$ pada taraf nyata 5 persen $(\alpha=0,05)$ dengan nilai signifikan 0,09 lebih kecil dari $\alpha=0,05$. Hal ini menunjukkart bahwa biaya promosi $\left(\mathrm{X}_{1}\right)$, biaya iklan $\left(\mathrm{X}_{2}\right)$, biaya outlet $\left(\mathrm{X}_{3}\right)$, dan biaya distribusi $\left(\mathrm{X}_{4}\right)$ secara bersama-sama berpengaruh nyata terhadap volume penjualan $(\mathrm{Y})$.

Nilai koefisien determinasi $\left(\mathrm{R}^{2}\right)$ diperoleh 0,946, menunjukkan bahwa 94,6 persen keragaman volume penjualan $(\mathrm{Y})$ mampu dijelaskan oleh keragaman biaya promosi $\left(\mathrm{X}_{1}\right)$, biaya iklan $\left(\mathrm{X}_{2}\right)$, biaya outlet $\left(\mathrm{X}_{3}\right)$, dan biaya distribusi $\left(\mathrm{X}_{4}\right)$. Sisanya 5,4 persen keragaman volume penjualan dijelaskan oleh variabel lain diluar model. Selain itu juga nilai koefisien korelasi $(\mathrm{R})$ sebesar 0,972 menunjukkan bahwa volume penjualan (Y) berhubungan erat dengan biaya promosi $\left(\mathrm{X}_{1}\right)$, biaya iklan $\left(\mathrm{X}_{2}\right)$, biaya outlet $\left(\mathrm{X}_{3}\right)$, dan biaya distribusi $\left(\mathrm{X}_{4}\right)$.

Tabel 5. ANOVA Regresi Linear Berganda, Pengaruh Kebijakan Anggaran Pemasaran Terhadap Volume Penjualan Produk Mie Instan PT. Indofood CBP Sukses Makmur, Tbk di Baubau.

\begin{tabular}{lrrrr}
\hline Sumber & Derajat Bebas & Koefisien Regresi & \multicolumn{1}{l}{$\mathrm{F}_{\text {hitung }}$} & \multicolumn{1}{c}{ Sig. F. } \\
\hline Regresi & 4 & 5,197 & $17,417^{\mathrm{n}}$ & 0,009 \\
\hline Regresi & 4 & 0,298 & & \\
\hline Total & 8 & 5,496 & & \\
\hline $\mathrm{R}^{2}$ & 0,946 & & & \\
\hline $\mathrm{R}$ & 0,972 & & & \\
\hline
\end{tabular}

Keterangan: $\mathrm{n}=$ nyata pada taraf $5 \%$

\section{Pengujian Variabel Bebas}

Pengujian variable bebas digunakan untuk melihat pengaruh variabel bebas $(X)$ yakni biaya promosi $\left(X_{1}\right)$, biaya iklan $\left(X_{2}\right)$, biaya outlet $\left(X_{3}\right)$, dan biaya distribusi $\left(X_{4}\right)$ secara parsial terhadap variabel tak bebas (Y) yakni volume penjualan dengan menggunakan uji t. Jika masing - masing variabel bebas (X) mempunyai hubung;an yang positif dan berpengaruh nyata terhadap variabel tak bebas (Y) mengidentifikasikan bahwa sernakin tinggi biaya promosi $\left(\mathrm{X}_{1}\right)$, biaya iklan $\left(\mathrm{X}_{2}\right)$, biaya outlet $\left(\mathrm{X}_{3}\right)$, dan biaya distribusi $\left(\mathrm{X}_{4}\right)$ maka volume penjualan (Y) semakin tinggi. Jika masing - masing variabel bebas $(\mathrm{X})$ mempunyai hubungan yang negatif dan tidak berpengaruh nyata terhadap variabel tak bebas (Y) mengidentifikasikan bahwa semakin tinggi biaya promosi $\left(\mathrm{X}_{1}\right)$, biaya iklan $\left(\mathrm{X}_{2}\right)$, biaya outlet $\left(\mathrm{X}_{3}\right)$, dan biaya distribusi $\left(\mathrm{X}_{4}\right)$, maka volume penjualan $(\mathrm{Y})$ akan semakin menurun. Hasil pengujian nilai parameter regresi linear berganda, pengaruh kebijakan anggaran pemasaran terhadap volume 
penjualan produk mie instan PT Indofood CBP Sukses Makmur, seperti pada Tabel 6 :

Tabel 6. Nilai Parameter Regresi Linear Berganda, Pengaruh Kebijakan Anggaran Pemasaran Terhadap Volume Penjualan Produk Mie Instan PT Indofood CBP Sukses Makmur, Tbk di BauBau.

\begin{tabular}{lrrr}
\hline \multicolumn{1}{c}{ Variabel Bebas } & Koefisien regresi & \multicolumn{1}{c}{$\mathrm{t}_{\text {hitung }}$} & Sig.t \\
\hline Konstanta & 33,693 & $1,292^{\mathrm{m}}$ & 0,266 \\
Biaya Promosi $\left(\mathrm{X}_{1}\right)$ & 10,119 & $1,856^{\mathrm{n}}$ & 0,014 \\
Biaya Iklan $\left(\mathrm{X}_{2}\right)$ & 9,138 & $1,767^{\mathrm{n}}$ & 0.015 \\
Biaya Outlet $\left(\mathrm{X}_{3}\right)$ & 2.432 & $1,894^{\mathrm{n}}$ & 0,042 \\
Biaya Distribusi $\left(\mathrm{X}_{4}\right)$ & 2,068 & $1,422^{\mathrm{n}}$ & 0,023 \\
\hline
\end{tabular}

Koefisien determinasi $\left(\mathrm{R}^{2}\right)$ 0,946

Keterangan : $\mathrm{n}=$ nyata pada tingkat kepercayaan $95 \%$

tn $=$ tidak nyata pada tingkat kepercayaan $95 \%$

\section{a. Biaya Promosi}

Biaya Promosi $\left(\mathrm{X}_{1}\right)$ mempunyai koefisisen regresi $(\mathrm{bi})=10,119$ dengan nilai signifikan 0,014 lebih kecil dari $\alpha=0,05$ yang berarti bahwa biaya promosi $\left(\mathrm{X}_{1}\right)$ berhubungan positif dan berpengaruh nyata terhadap volume penjualan (Y). Jika biaya promosi meningkat Rp 1 maka volume penjualan akan meningkat sebesar Rp 10,119 dengan asumsi variabel lain dianggap tetap (ceteris paribus) atau dengan kata lain jika biaya promosi ditingkatkan $1 \%$ maka akan meningkatkan volume pandapatan sebesar $0,004 \%$.

Biaya promosi penjualan berpengaruh nyata terhadap volume penjualan karena promosi penjualan merupakan faktorutama yang menunjang pertumbuhan penjualan produk mie instan atau merupakan bagian yang dipergunakan untuk memperbanyak dan mengembangkan kegiatan penjualan. Biaya promosi menjadi konsekuensi biaya yang harus dikeluarkan perusahaan agar produk yang dijual lebih dikenal masyarakat.

\section{b. Biaya Iklan}

Biaya Iklan $\left(\mathrm{X}_{2}\right)$ mempunyai koefisisen regresi $\left(\mathrm{b}_{2}\right)=9,138$ dengan dengan nilai signifikan 0.015 lebih kecil dari $\alpha=0,05$ yang berarti bahwa biaya iklan $\left(\mathrm{X}_{1}\right)$ berhubungan positif dan berpengaruh nyata terhadap volume penjualan (Y). Jika biaya iklan meningkat Rp 1 maka volume penjualan akan meningkat sebesar Rp 9,138 dengan asumsi variabel lain dianggap tetap (ceteris paribus) atau dengan kata lain jika biaya iklan ditingkatkan $1 \%$ maka akan meningkatkan volume pandapatan sebesar $0,002 \%$.

Biaya iklan berpengaruh nyata terhadap volume penjualan karena iklan merupakan faktor utama lainnya yang menunjang pertumbuhan penjualan produk mie instan atau merupakan bagian yang dipergunakan untuk memperbanyak dan mengembangkan kegiatan penjualan. Selain itu juga, biaya iklan dialokasikan agar mengubah permintaan produk yang dijual dengan harapan konsumen membeli lebih banyak dari biasanya.

\section{c. Biaya Outlet}

Biaya outlet $\left(X_{3}\right)$ mempunyai koefisien regresi $\left(b_{3}\right)=2,432$ dengan nilai signifikan 0,042 lebih kecil dari $\alpha=0,05$ berarti bahwa biaya outlet $\left(X_{3}\right)$ berhubungan positif dan 
berpengaruh nyata terhadap volume penjualan (Y). Jika biaya outlet meningkat Rp 1 maka volume penjualan akan meningkat sebesar Rp 2,432 dengan asumsi variabel lain dianggap tetap (ceteris paribus) atau dengan kata lain jika biaya outlet ditingkatkan 1\% maka akan meningkatkan volume pandapatan sebesar $0,001 \%$.

Biaya outlet berpengaruh nyata terhadap volume penjualan karena outlet merupakan faktor penunjang pertumbuhan penjualan produk mie instan atau merupakan bagian yang dipergunakan untuk memperbanyak dan mengembangkan kegiatan penjualan. Biaya outlet yang berpengaruh tersebut mengindikasikan penggunaan jasa pelayanan penjualan yang dibiayai oleh perusahaan untuk mempertemukan masyarakat dengan produk mie instan. Naiknya biaya outlet menunjukkan adanya pemanfaatan mitra kerja di pasar untuk memungkinkan naiknya tingkat penjualan.

\section{d. Biaya Distribusi}

Biaya distribusi $\left(\mathrm{X}_{4}\right)$ mempunyai koefisien regresi $\left(\mathrm{b}_{4}\right)=2,068$ dengan nilai signifikan 0,023 lebih kecil dari $\alpha=0,05$ berarti bahwa biaya distribusi $\left(\mathrm{X}_{4}\right)$ berhubungan positif dan berpengaruh nyata terhadap volume penjualan (Y). Jika biaya distribusi meningkat sebesar Rp 1 maka volume penjualan akan meningkat sebesar Rp 2,068 dengan asumsi variabel lain dianggap tetap (ceteris paribus) atau dengan kata lain jika biaya distribusi ditingkatkan $1 \%$ maka akan meningkatkan volume pandapatan sebesar $0,001 \%$.

Biaya distribusi berpengaruh nyata terhadap volume penjualan karena distribusi merupakan faktor yang menunjang pertumbuhan penjualan produk mie instan atau merupakan bagian yang dipergunakan untuk memperbanyak dan mengembangkan kegiatan penjualan. Distribusi produk merupakan perluasan penjualan sehingga membutuhkan biaya sesuai dengan luasnya pendistribusiannya.

\section{Analisis Trend Volume Penjualan}

Trend penjualan yang dimiliki perusahaan dalam setiap penjualan menunjukkan aktivitas promosi, iklan, outlet dan distribusi yang dilakukan secara bersama untuk dapat mencapai tujuan perusahaan dalam memasarkan produksi mie instan. Dalam tahun 2010-2014 perusahaan memiliki trend penjualan yang berubah-ubah seiring dengan kegiatan perusahaan.

Pada penelitian ini trend volume penjualan mie instan pada 9 (sembilan) tahun terakhir mengalami peningkatan tetapi pada penjualan quartal bersifat tetap, namun untuk menganalisis trend volume penjualan pada tahun mendatang digunakan analisis time series. 
Tabel 7. Trend Volume Penjualan Mie Instan di Kota Baubau Periode 2010 -2014.

\begin{tabular}{cc}
\hline Tahun & Penjualan (Miliar Rp) \\
\hline 2010 & 160,279 \\
\hline 2011 & 168,715 \\
\hline 2012 & 175,745 \\
\hline 2013 & 184,995 \\
\hline 2014 & 190,716 \\
\hline Rata-rata & 159,406 \\
\hline
\end{tabular}

\section{Sumber : Data diolah}

Apabila data pada Tabel 7 dianalisis dengan persamaan : $\mathrm{Y}=\mathrm{a}+\mathrm{bX}$, maka diperoleh persamaan trend volume penjualan pada tahun mendatang yakni:

$$
\mathrm{Y}=0,290+6,553 \mathrm{X}
$$

Koefisien regresi $(b)=6,553$ menunjukkan bahwa peningkatan volume penjualan yang terjadi setiap periode penjualan berdasarkan kebijakan anggaran adalah sebesar 6,553 karton yang berarti bahwa secara statistik model penduga cukup baik dan signifikan dalam mempredisksi trend penjualan di masa mendatang. Hal ini mengindikasikan bahwa dalam kegiatan pemasaran dengan menggunakan kebijakan anggaran akan meningkatkan volume penjualan.

Tabel 8. Estimasi Volume Penjualan Mie Instan di Kota Baubau Periode 2010-2015.

\section{Tahun Penjualan (Miliar Rp)}

\begin{tabular}{cc}
\hline 2011 & 164,550 \\
\hline 2012 & 180,933 \\
\hline $2013^{\prime}$ & 197,315 \\
\hline 2014 & 213,698 \\
\hline 2015 & 230,080 \\
\hline Rata-Rata & 197,315 \\
\hline
\end{tabular}

Sumber : Data diolah 2014

Tabel 8 menenunjukkan bahwa faktor yang mempengaruhi kebijakan anggaran merupakan factor yang mendorong terwujudnya kegiatan penjualan perusahaan. Faktor tersebut dikombinasikan dengan keberadaan perusahaan di dalam lingkungan pasar yang bersaing secara kompetitif untuk mempertahankan pelanggan dan memperluas pangsa pasar. Kebijakan anggaran yang dilakukan perusahaan pemasaran adalah keputusan-keputusan yang sifatnya mengikat bagi perusahaan pada tataran strategis untuk memperoleh anggaran yang akan digunakan dalam kegiatan pemasaran produk mi instan. 
Nugroho (2006), menjelaskan bahwa oleh karena kebijakan merupakan keputusan yang mengikat anggota dari suatu organisasi maka kebijakan haruslah dibuat oleh organisasi bersangkutan, yakni mereka yang menerima mandat dari perusahaan. Kebijakan dibuat untuk mengatasi permasalahan yang dihadapi dan menjadi solusi terhadap penyelesaian permasalah tersebut. Dalam penelitian ini permasalahan anggaran per quartal merupakan permasalahan internal perusahaan yang dapat menghambat perusahaan dalam pelaksanaan promosi penjualan, iklan, outlet dan pendistribusian barang. Hal ini sama seperti pada hasil analisis regresi linear berganda yang diperoleh bahwa anggaran untuk promosi penjualan, iklan, outlet dan pendistribusian barang secara parsial maupun bersama-sama mempunyai pengaruh terhadap volume penjualan.

Berhubungan dengan perencanaan anggaran, penggunaan anggaran telah efektif tetapi tidak meningkatkan volume penjualan dalam quartalan tetap peningkatan terjadi pada akhir periode penjualan pada setiap tahun. Hal ini disebabkan juga oleh proses perencanaan anggaran dimana setiap perusahaan memperhitungkan kondisi yang terjadi baik kondisi internal maupun kondisi ekstemal untuk melakukan penganggaran. Menurut Sofian (2000), kebijakan anggaran sangat berpengaruh terhadap setiap aktivitas perusahan-perusahaan maka para pemimpin perusahaan diharapkan dapat menetapkan strategi anggaran yang stabil. Amstrong (2000), juga menjelaskan bahwa proses perencanaan anggaran pada suatu perusahaan, dihadapkan dengan angka-angka aktual yang harus dibandingkan dengan angkaangka yang dianggarkan dalam setiap periode waktu tertentu. Alasan- alasan mengenai adanya variance anggaran harus diketahui dengan jelas penyebab dan dasar pertimbangannya. Variance biaya penjualan harus dapat dipisahkan dari variasi biaya lainnya seperti biaya tenaga kerja, biaya overhead kantor dan biaya perawatan fasilitas.

Kondisi efektivitas penggunaan anggaran dalam pelaksanaan kegiatan pada penjualan mie instan lebih banyak menitik beratkan pada tindakan hati-hati terhadap kegiatan penjualan. Banyak produk yang terjual pada perusahaan diseimbangkan dengan pemakaian keempat jenis biaya tersebut. Dengan demikian dapat dikemukakan bahwa penggunaan anggaran dapat meningkatkan volume penjualan pada salah satu sisi dan keuntungan perusahaan disisi lainnya.

\section{SIMPULAN DAN SARAN}

\section{Simpulan}

Berdasarkan hasil penelitian tersebut, maka dapat disimpulkan sebagai berikut:

1. Biaya promosi, biaya iklan, biaya outlet dan biaya distribusi berhubungan positif dan secara simultan maupun parsial berpengaruh nyata terhadap volume penjualan produk mie instan pada PT. Indofood CBP Sukses makmur, Tbk Baubau. Berdasarkan nilai elastisitasnya, biaya promosi ditingkatkan $1 \%$ maka akan meningkatkan volume penjualan $0,004 \%$, biaya iklan ditingkatkan $1 \%$ maka akan meningkatkan volume penjualan $0,002 \%$, biaya outlet ditingkatkan $1 \%$ maka akan meningkatkan volume penjualan $0,001 \%$, dan biaya distribusi ditingkatkan $1 \%$ maka akan meningkatkan volume penjualan $0,001 \%$. Atau dengan kata lain, volume penjualan tidak responsive (inelastis) terhadap pembahan faktor-faktor yang mempengaruhinya.

2. Volume penjualan produk mie instan pada PT. Indofood CBP Sukses Makmur, Tbk Baubau pada tahun 2010 sampai 2014 mengalami peningkatan dengan rata-rata volume penj ualan 159,406 miliar rupiah per tahun. Sedangkan tahun 2015 volume penjualan 
rata-rata akan mencapai 197,315 miliar rupiah per tahun.

\section{Saran}

Berdasarkan kesimpulan yang dikemukakan, maka dapat disarankan untuk dapat meningkatkan volume penjualan produk pada masa yang akan datang, maka biaya atau anggaran yang dialokasikan perusahaan untuk kegiatan promosi, iklan, outlet dan distribusi harus dilakukan penambahan anggaran sehingga volume penjualan meningkat.

\section{DAFTAR PUSTAKA}

Amstrong, J W. 2000. Manajemen Pemasaran, Perhalindo, Jakarta

Kotler, P. 2002. Manajemen Pemasaran, Perhalindo. Jakarta.

Nugroho, D, 2006. Analisis Kebijakan Anggaran, Elex Media Komputerindo, Jakarta.

Ridwan, 2006, Analisis Data Statistik, ALFABETA. Bandung.

Sofyan, 2000. Manajemen Pemasaran. Liberty, Yogyakarta.

Suhyani, 2000. Analisis Kebijakan Anggaran pada Perusahaan Jasa. Murai Kencana, Jakarta. 